\title{
Impact of Vaccine Manufacturing Announcement During Pandemic on The Stock Market Reaction of Pharmaceutical Companies
}

\author{
Cellina Trishana \\ School of Business and Management, Bandung Institute of Technology, Indonesia \\ Email: cellina_trishana@sbm-itb.ac.id
}

\begin{tabular}{l} 
ARTICLE INFO \\
\hline Received: 05-01-2022 \\
Revision: 13-01-2022 \\
Received : 18-01-2022 \\
\hline Keywords: \\
Abnormal return; trading \\
volume activity; market \\
reaction; event study
\end{tabular}

\section{Introduction}

The capital market has a significant role in the economic condition of a country. It funds businesses and is a place for people to invest in the long term through stocks, bonds, mutual funds, and others (Pratama, Sinarwati, Darmawan, \& SE, 2015). By trading financial instruments, the capital market acts as a liaison between investors and companies or government agencies.

The world was astonished when the Corona Virus Disease (COVID-19) emerged in early 2020, quickly becoming a global health be expanded.
The objective of this research is to identify whether there is a significant difference in the market reaction shown by the abnormal return and trading volume activity before and after the vaccine manufacturing announcement conducted by listed pharmaceutical companies around the world. The sample used in this research is listed pharmaceutical companies that conducted a vaccine manufacturing announcement during a pandemic, and the data collected is secondary data. This wearch uses the event study as its methodology with 3 event windows, announcement. The analysis of the normality test and paired difference test is conducted using the Wilcoxon Signed Rank Test with a significance level of 0.05 . The result shows that there is no significant manufacturing announcement. From this research, it can be concluded that the vaccine manufacturing announcement during a pandemic does not have a significant effect on the market reaction. To extend and further test the market reaction of pharmaceutical companies, future esearch could be done by exploring more on the effect of health-related news on all pharmaceutical companies, and the variables tested could

$\begin{array}{ll}\text { How To Cite: } & \begin{array}{l}\text { Trishana, C., (2022) Impact of Vaccine Manufacturing Announcement During Pandemic on The } \\ \text { Stock Market Reaction of Pharmaceutical Companies. Journal of Social Science. 3(1). } \\ \\ \text { https://doi.org/10.46799/jss.v3i1.200 }\end{array} \\ \text { E-Issn: } & \begin{array}{l}2721-5202 \\ \text { Published By: }\end{array} \quad \text { Ridwan Institut }\end{array}$

issue. The virus's spread accelerated until, on March 11th, 2020, WHO declared COVID-19 a global pandemic that disrupts human activities, including the country's economic vitality. This virus is known to cause pneumonia in its victims and is thought to be non-airborne (i.e., it cannot be spread through the air), but it can be spread through physical contact (Khoiriah, 2020).

On March 2nd, 2020, the government of Indonesia officially revealed the first COVID-19 case, which included two positive cases. As a result, in order to reduce the spread of COVID- 
19, local and national governments had to establish minimum physical distance restrictions to limit physical contact between people. This was followed by the installation of large-scale social restrictions known as Pembatasan Sosial Berskala Besar (PSBB), which was one of the government's measures to stop the virus from spreading by forcing people to stay at home and temporarily blocking roadways and populated areas (Baker, Bloom, Davis, \& Terry, 2020).

The COVID-19 pandemic is a fascinating occurrence to investigate in terms of stock price fluctuations. Furthermore, as a result of the pandemic, share trading activity has plummeted. On April 17th, 2020, the Composite Stock Price Index (IHSG) fell by 26.43 percent to 4,635 , followed by a -26.11 percent reduction in market capitalisation to IDR 5,368 trillion. The average daily transaction frequency decreased by 1.49 percent to 462,000 transactions per day, while the average daily transaction value decreased by 23.84 percent to IDR 6.94 trillion.

Due to the panic in society that has affected the market, the COVID-19 pandemic has also reduced capital flows in some nations, lowering market confidence, especially in countries that are slow to stop the virus's spread (Baldwin \& Di Mauro, 2020).

This virus has had a significant influence on the Indonesian capital market sector, as seen by the weakening of IHSG's negative market sentiment and the effect of weakening international markets, resulting in the Indonesian IHSG crossing the red line. When the government proclaimed a national emergency and declared holidays on March 7th, 2020, investors' anxieties grew.

The composite stock price index closed down 1.3 percent at 3,937 on March 24th, 2020. IHSG also fell out of the top eight for the first time. IHSG has plummeted to 3,000 on June 24th, 2012, and was now at 3,955.58 (Pitaloka, Al Umar, Hartati, \& Fitria, 2020).

On March 24th, 2020, the composite stock price index fell 1.3 percent to 3,937. For the first time, IHSG dropped out of the top eight. On June 24th, 2012, IHSG fell to 3,000 and is now at 3,955.58 (Bash, 2020).

One of the elements that can affect the capital market is a change in economic conditions as a result of an event. This might cause stock prices on the stock exchange to fluctuate, thus causing financial gains or stock returns to be uncertain (Gupta, 2014). Market participants (investors) require information in order to accurately forecast the accuracy of investing funds in order to obtain the predicted return each time they participate in the capital market (Hartono, 2017).

The COVID-19 epidemic had an indirect impact on the Indonesia Stock Exchange, as well as other countries' stock exchanges. In this instance, investors obviously want to invest with the least amount of danger, and this incident causes investors to be cautious while investing their cash in the capital market (Mujib, 2021).

The COVID-19 pandemic is an outbreak for which no precise end date has been established; as a result, information has become increasingly important for investors in stock forecasting activities of publicly traded corporations. This epidemic poses a serious threat, particularly in emerging countries, where the economic system is unstable.

The following are the hypotheses that will be investigated in this study, based on the foregoing explanation:

HO: There is a significant abnormal return difference between one month, ten days, and five days before vaccine manufacturing announcement and one month, ten days, and five days after vaccine manufacturing announcement one month, ten days, and five days after vaccine manufacturing announcement.

$\mathrm{H} 1$ : There is no substantial abnormal return difference between one month, ten days, and five days before vaccine manufacturing announcement and one month, ten days, and five days after vaccine manufacturing announcement one month, ten days, and five days after vaccine manufacturing announcement.

$\mathrm{HO}$ : There is no discernible variation in trade volume activity one month, ten days, and five days prior to vaccine production announcement and one month, ten days, and five days following vaccine manufacturing announcement.

$\mathrm{H} 2$ : There is no discernible variation in trade volume activity one month, ten days, and five days prior to vaccine production announcement and one month, ten days, and five days following vaccine manufacturing announcement. 


\section{Method}

The population for this study is all listed firms in 2020-2021 who meet the criteria of being actively traded and listed on each country's stock exchange from December 1, 2019 to July 1, 2021.

The purposive sampling approach will be used in this study, and the research sample will consist of 20 publicly traded pharmaceutical companies that meet the following criteria:

1. Actively traded and listed pharmaceutical companies included in the stock exchange of each country from December 1st, 2019 to July 1st, 2021.

2. Listed pharmaceutical companies that announced a vaccine manufacturing permit and/or distribution from December 1st, 2019 - to July 1st, 2021.

Estimation Period
The data used in this research is secondary data. Data taken comes from several sources which are:

1. The daily share price of sample companies gathered from Yahoo! Finance (finance.yahoo.com).

2. The total number of the companies' daily shares traded and the number of outstanding shares gathered from the website of each countries' stock exchange and Yahoo! Finance (finance.yahoo.com).

There are 3 event windows to be used in this research, namely; one month before and after the announcement, five days before and after the announcement, five days before and after the announcement. Each of the event windows uses 2 months before the event window as the estimation period.

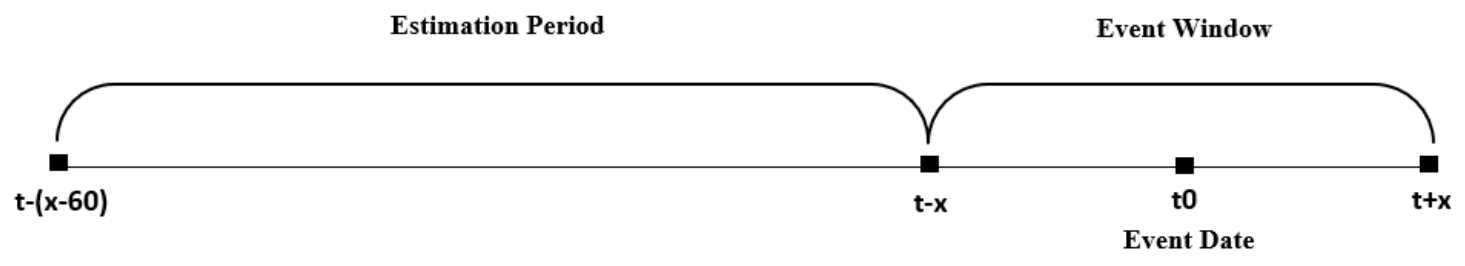

Figure 1: Event Period

After the secondary data has been processed into abnormal return and trading volume activity in the form of daily stock prices, the number of shares exchanged, and the number of shares outstanding, the data will be subjected to a normalcy test and paired difference test.

The normality test determines whether or not the data is normally distributed, which determines the optimal procedure for doing the paired difference test. If the data is normally distributed, the paired difference test will be performed using the Paired Sample T-Test, a parametric statistical tool. Otherwise, a nonparametric statistical method called the Paired Sample Wilcoxon Signed Rank Test will be used to perform the paired difference test. 


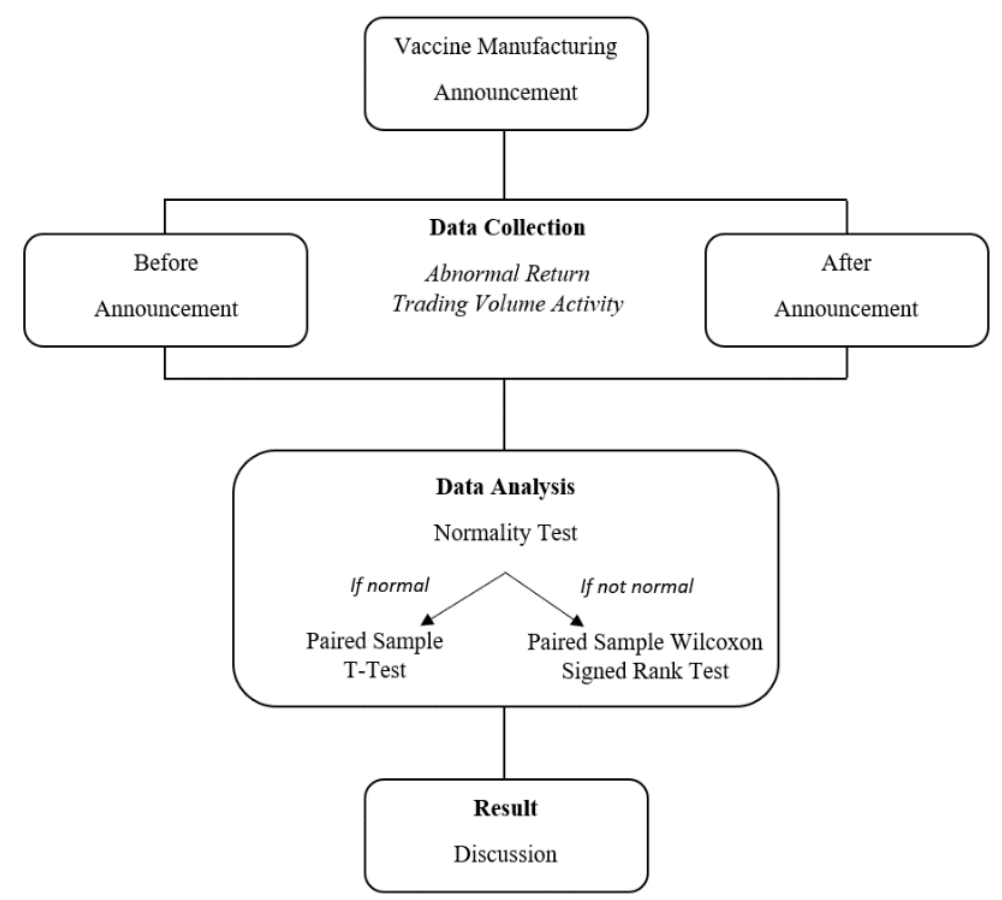

Figure 2: Research Design

The author will initially compute the stock individual return before processing the acquired data into an abnormal return (Rit). According to (Hartono, 2014), the stock individual return can be calculated with the formula:

$$
\boldsymbol{R}_{\text {it }}=\frac{\boldsymbol{P}_{\text {it }}-\boldsymbol{P}_{\text {it }-1}}{\boldsymbol{P}_{\text {it }-1}}
$$

Equation 1: Stock Individual Return

Rit $\quad=$ Return of stock I in period $\mathrm{t}$

Pit $\quad=$ Price of stock $\mathrm{I}$ in period $\mathrm{t}$

Pit-1 = Price of stock $\mathrm{I}$ in period $\mathrm{t}-1$

The author will next compute the market return (Rmt), with the assumption that the degree of profit in the market portfolio is the influencing factor of stock return. The market return formula is as follows:

$$
\boldsymbol{R}_{m t}=\frac{C S P I_{t}-C S P I_{t-1}}{C S P I_{t-1}}
$$

Equation 2: Market Return

Rmt $=$ Market return in period $\mathrm{t}$

CSPIt $=$ Composite stock price index in period $t$

CSPIt-1 = Composite stock price index in period $\mathrm{t}-1$

The data of individual stock return and market return will be regressed to obtain the alpha (a) and beta $(\beta)$ of each stock using the Single Index Model to calculate the expected return $(E(R i t))$. The author will apply one regression model for the three-event windows, with the data of 40 daily stock prices of each company ( 2 months before the event windows). Then, the expected return will be calculated with the following formula:

$$
E\left(R_{i t}\right)=\alpha_{i}+\beta_{i} E\left(R_{m t}\right)
$$
Equation 3: Expected Return

it $=$ Abnormal return of stock $\mathrm{I}$ in period

$t$

Rit $\quad=$ Return of stock $\mathrm{I}$ in period $\mathrm{t}$

$\mathrm{E}(\mathrm{Rit})=$ Expected return of stock $\mathrm{I}$ in period $\mathrm{t}$

In the end, the abnormal return will be obtained by calculating the difference between the actual return and the expected return. The formula of abnormal return is:

$$
\begin{aligned}
& \boldsymbol{A} \boldsymbol{R}_{i t}=\boldsymbol{R}_{i t}-\boldsymbol{E}\left(\boldsymbol{R}_{i t}\right) \\
& \text { Equation 4: Abnormal Return }
\end{aligned}
$$

$\mathrm{E}($ Rit $)=$ Expected return of stock $\mathrm{I}$ in period $\mathrm{t}$

ai = Part of stock $\mathrm{I}$ return that is not influenced by market performance (intercept stock i)

$\beta \mathrm{i}=$ Sensitivity of stock I return to market movements (slope coefficient, beta stock i)

Rmt $=$ Market return in period $\mathrm{t}$ 
Trading Volume Activity (TVA) is one of the measures used to determine how the stock market reacts to a certain event or piece of information. According to (Rofiki, Topowijono, \& Nurlaily, 2018), trading volume activity is defined as the ratio of the number of shares exchanged at a certain moment to the number of outstanding shares of a firm over a given period, with the formula being:

$$
\boldsymbol{T V} \boldsymbol{A}_{\text {it }}=\frac{\boldsymbol{V}_{\text {it }}}{V \boldsymbol{m}_{\text {it }}}
$$

Equation 5: Trading Volume Activity

Tveit = Trading volume activity of stock I in period $\mathrm{t}$

Vit $=$ Total volume of stock I traded in period $\mathrm{t}$

Vomit $=$ Total number of shares outstanding of the company $\mathrm{I}$ in period $\mathrm{t}$

The normality test will be performed on both the data (abnormal return and trade volume activity). The purpose of a normality test is to determine whether or not the data is regularly distributed. The Shapiro-Wilk Test will be used in this study because it is the best test method for a small sample size (50 samples). Furthermore, in contrast to other approaches that are more broad, the Shapiro-Wilk Test is a specialized test for normality, making it more powerful and yielding superior findings (Razali \& Wah, 2011).

SPSS 22.0 will be used to perform the normalcy test, which will have a $5 \%$ significance level (0.05). The Sig function in SPSS displays the data's p-value. section. The following test criteria can be used to assess the significance level of the normality test:

1. If the significance (Sig. $>\alpha(0.05)$ ), then the data is normally distributed.

2. If the significance (Sig. $<\alpha(0.05)$ ), then the data is not normally distributed.

The basic goal of the paired difference test is to perform a statistical hypothesis test to determine whether $\mathrm{H} 1$ and $\mathrm{H} 2$ are rejected or accepted. Based on the results of the normality test, the type of paired difference test that will be applied on the data will be chosen. If the data is regularly distributed, the paired difference test will use the Paired Sample TTest, a parametric statistical technique. Otherwise, the paired difference test will use the Paired Sample Wilcoxon Signed Rank Test, which is a non-parametric statistical method.

\section{Paired Sample T-Test}

The paired sample T-Test is a test that compares the means of two samples that are connected to each other (paired). Paired samples are samples from the same person who have undergone two separate treatments or measurements (Priyatno, 2012). The average difference between paired samples is the focus of this test. This test should be conducted using regularly distributed data. The Paired Sample T-Test will utilize a significance level of $5 \%$ with the following research criteria to assess the significance level of the hypothesis:

1. If the $\mathrm{T}$ significance $>\alpha(0.05), \mathrm{HO}$ is rejected, implying that there is no significant difference in the variables before the vaccine manufacturing announcement and after the vaccine manufacturing announcement.

2. If the $\mathrm{T}$ significance $<\alpha(0.05), \mathrm{HO}$ is accepted, implying that there is a significant difference in the variables before the vaccine manufacturing announcement and after the vaccine manufacturing announcement

\section{Paired Sample Wilcoxon Signed Rank Test}

Sample with a Partner The Wilcoxon Signed Rank Test is a non-parametric statistical tool for analyzing paired data having features that are not normally distributed. The Wilcoxon Signed Rank Test is based on the data's median, which allows the result to be free of outlier effects (Woolson, 2007).

To determine the significance level of the hypothesis, the Paired Sample Wilcoxon Signed Rank Test will use a significance level of $5 \%$ with the following research criteria:

1. If the Asymp. Sig. (2-tailed) $>\alpha(0.05), \mathrm{HO}$ is rejected, implying that there is no significant difference in the variables before the vaccine manufacturing announcement and after the vaccine manufacturing announcement.

2. If the Asymp. Sig. (2-tailed) $<\alpha(0.05), \mathrm{HO}$ is accepted, implying that there is a significant difference before the vaccine manufacturing announcement and after the vaccine manufacturing announcement. 
Results And Discussion

Descriptive Statistic of Abnormal Return

a. One month event window

\begin{tabular}{lcccc} 
& Minimum & Mean & Maximum & Std. Deviation \\
\hline Before Announcement & -0.020120 & -0.00054095 & 0.035082 & 0.010345727 \\
\hline During Announcement & -0.099344 & 0.05469965 & 0.217775 & 0.089538273 \\
\hline After Announcement & -0.018766 & 0.00098004 & 0.030180 & 0.013179684
\end{tabular}

Table 1 shows the descriptive statistics of aberrant returns in a one-month event window before and after the vaccine manufacturing announcement. The AAR before vaccine manufacture is -0.00054095 or $-0,054$ percent for the whole companies, and the AAR after vaccine manufacturing announcement is 0.00098004 or 0.098 percent. The abnormal returns following the vaccine production announcement are, on average, higher than

the abnormal returns before to the vaccine manufacturing announcement. The value of AAR before and after the vaccine manufacturing announcement in the onemonth event window indicates that market players (investors) had a positive reaction to the vaccine manufacturing announcement.

Figure 3 depicts the AAR for each day throughout the one-month period preceding and following the vaccine manufacturing announcement.

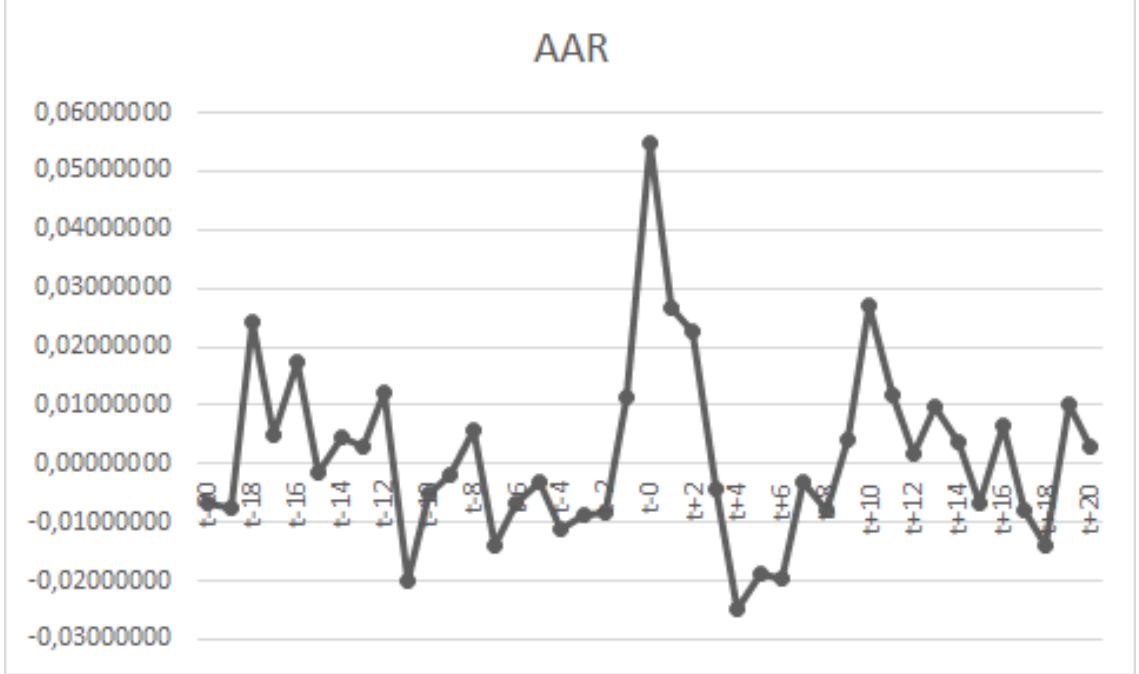

Figure 3: Average Abnormal Return for each day in one-month event window (Source: processed by author)

a. Ten days event window

Table 2: Average Abnormal Return in ten days event window (Source: SPSS 22.0, processed by author)

\begin{tabular}{lcccc}
\hline & Minimum & Mean & Maximum & Std. Deviation \\
\hline Before Announcement & -0.032802 & -0.00532738 & 0.010164 & 0.011078903 \\
\hline During Announcement & -0.098084 & 0.04290154 & 0.215829 & 0.081450900 \\
\hline After Announcement & -0.040603 & -0.00227297 & 0.057350 & 0.022690421 \\
\hline
\end{tabular}

In a ten-day event window, Table 2 shows the descriptive statistics of aberrant 
returns before and after the vaccine manufacturing announcement. The AAR before vaccine manufacturing is -0.00532738 or 0,533 percent for the whole companies, while the AAR after vaccine manufacturing announcement is -0.00227297 or -0.227 percent. The abnormal returns following the vaccine production announcement are, on average, higher than the abnormal returns before to the vaccine manufacturing announcement. The value of AAR before and after the vaccine manufacturing announcement in the ten-day event window indicates that market players (investors) had a positive reaction to the vaccine manufacturing announcement.

Figure 4 depicts the AAR for each day in the ten-day period preceding and following the vaccine manufacturing announcement.

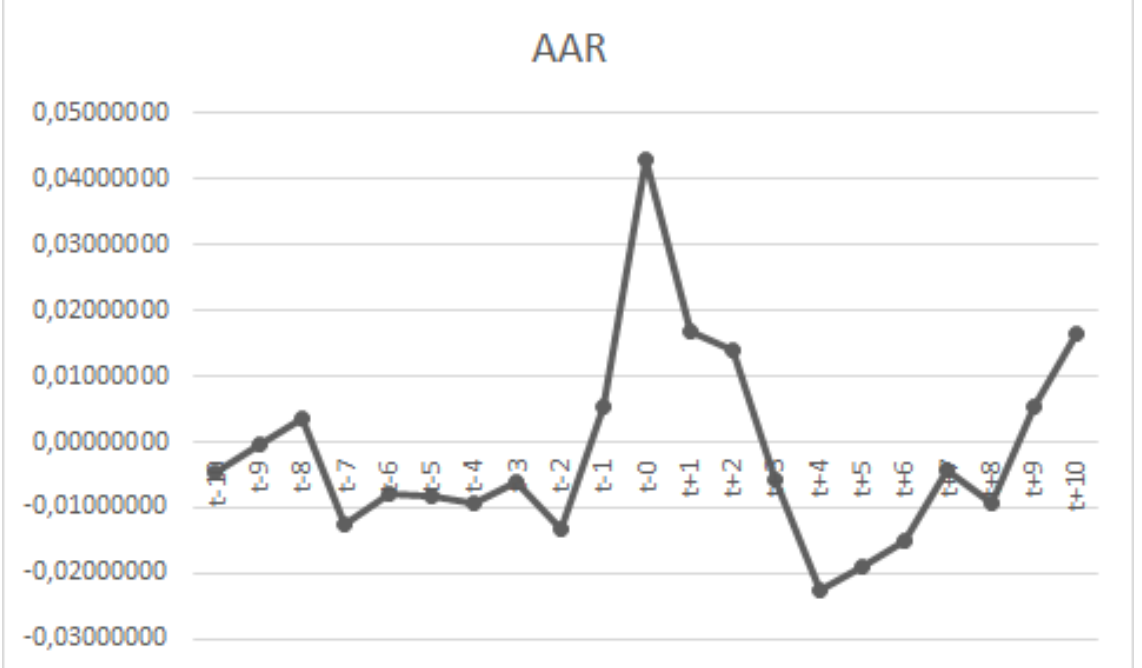

Figure 4: Average Abnormal Return for each day in ten days event window (Source: processed by author)

b. Five days event window

Table 3: Average Abnormal Return in five days event window (Source: SPSS 22.0, processed by author)

\begin{tabular}{lcccc}
\hline & Minimum & Mean & Maximum & $\begin{array}{c}\text { Std. } \\
\text { Deviation }\end{array}$ \\
\hline Before Announcement & -0.046717 & -0.00747998 & 0.020090 & 0.017320429 \\
\hline During Announcement & -0.141602 & 0.03993978 & 0.222557 & 0.087781669 \\
\hline After Announcement & -0.038920 & -0.00437695 & 0.078334 & 0.028973662
\end{tabular}

Table 3 shows the descriptive statistics of aberrant returns in a five-day event window before and after the vaccine production announcement. The AAR before vaccine manufacturing is -0.00747998 or $-0,748$ percent for the whole companies, while the AAR after vaccine manufacturing announcement is -0.00437695 or -0.438 percent. The abnormal returns following the vaccine production announcement are, on average, higher than the abnormal returns before to the vaccine manufacturing announcement. The value of AAR before and after the vaccine manufacturing announcement in the five-day event window indicates that market players (investors) had a positive reaction to the vaccine manufacturing announcement.

Figure 5 depicts the AAR for each day in the five-day period preceding and following the vaccine manufacturing announcement. 


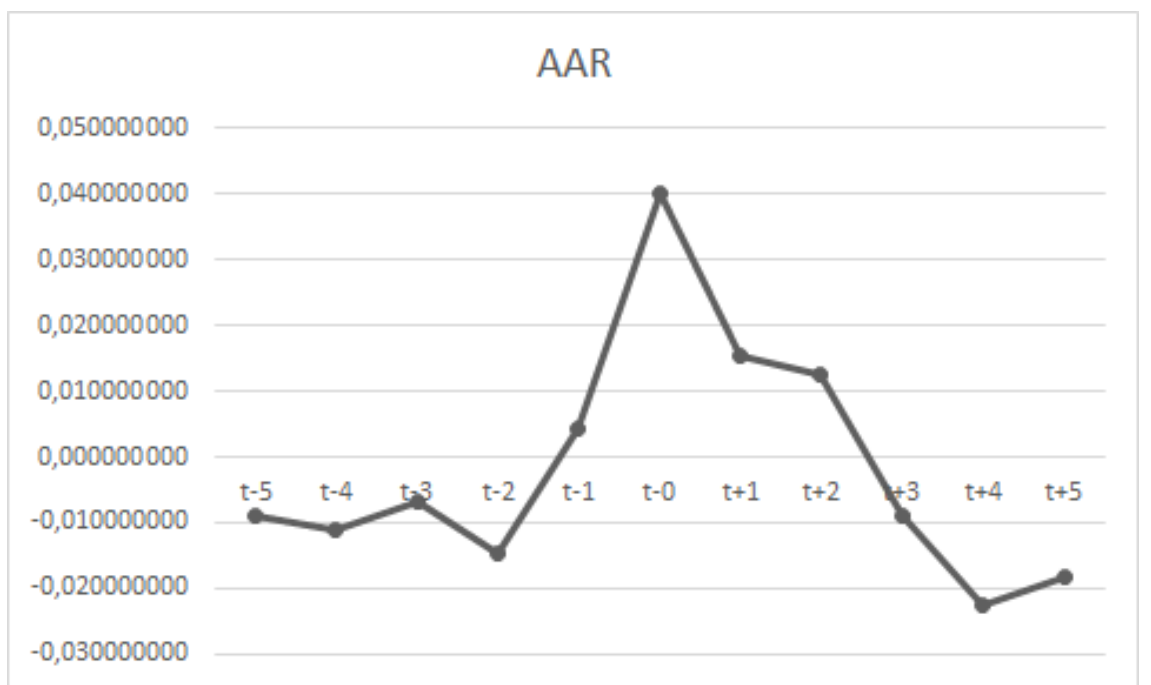

Figure 5: Average Abnormal Return for each day in five days event window (Source: processed by author)

Descriptive Statistic of Trading Volume Activity

a. One month event window

Table 4: Average Trading Volume Activity in one-month event window (Source: SPSS 22.0, processed by author)

\begin{tabular}{lcccc}
\hline & Minimum & Mean & Maximum & $\begin{array}{c}\text { Std. } \\
\text { Deviation }\end{array}$ \\
\hline $\begin{array}{l}\text { Before } \\
\text { Announcement }\end{array}$ & 0.001529 & 0.03036407 & 0.245135 & 0.055795163 \\
\hline $\begin{array}{l}\text { During } \\
\text { Announcement }\end{array}$ & 0.001866 & 0.02753141 & 0.118161 & 0.030710571 \\
\hline $\begin{array}{l}\text { After } \\
\text { Announcement }\end{array}$ & 0.00152 & 0.01421987 & 0.049763 & 0.014081569 \\
\hline
\end{tabular}

Table 4 shows the descriptive data of trading volume activity in a one-month event window before and after the vaccine manufacturing announcement. The ATVA before vaccine manufacture is 0.03036407 or 3,036 percent for the whole companies, and the ATVA after vaccine manufacturing is 0.01421987 or 1.422 percent. The trading volume activity after the vaccine manufacturing announcement is, on average, lower than the trading volume activity before the vaccine manufacturing announcement. The value of ATVA before and after the vaccine manufacturing announcement in the onemonth event window indicates that market players (investors) had a negative reaction to the vaccine manufacturing announcement.

Figure 6 depicts the ATVA for each day throughout the one-month period preceding and following the vaccine manufacturing announcement. 


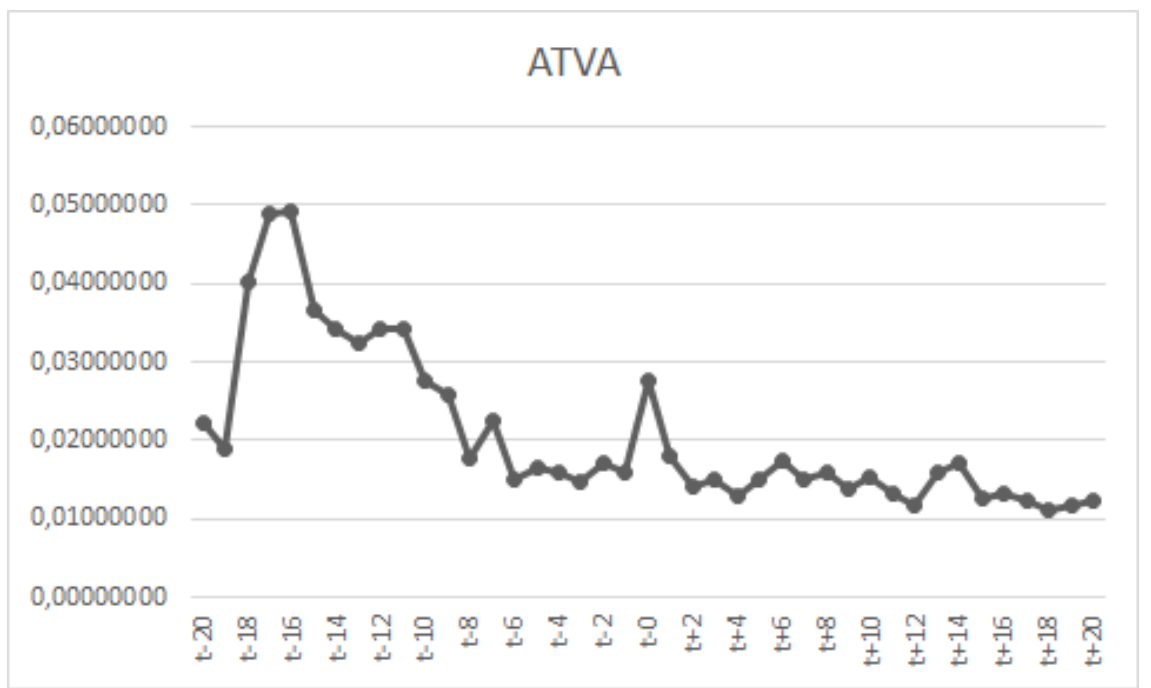

Figure 6: Average Trading Volume Activity for each day in one-month event window (Source: processed by author)

b. Ten days event window

Table 5: Average Trading Volume Activity in ten days event window (Source: SPSS 22.0, processed by author)

\begin{tabular}{|c|c|c|c|c|}
\hline & Minimum & Mean & Maximum & Std. Deviation \\
\hline $\begin{array}{l}\text { Before } \\
\text { Announcement }\end{array}$ & 0.001538 & 0.01888454 & 0.083802 & 0.022629637 \\
\hline $\begin{array}{l}\text { During } \\
\text { Announcement }\end{array}$ & 0.030710571 & 0.02753141 & 0.118161 & 0.030710571 \\
\hline After Announcement & 0.001504 & 0.01526633 & 0.056435 & 0.015901597 \\
\hline $\begin{array}{l}\text { Table } 5 \text { shows the } \\
\text { de volume activity in } \\
\text { and following the } v \\
\text { uncement. The AT } \\
\text { ufacture is } 0.018884 \\
\text { he whole companies, } \\
\text { ne manufacturing is } \\
\text { ent. The trading volu } \\
\text { ne manufacturing a }\end{array}$ & $\begin{array}{l}\text { lescriptive sta } \\
\text { he ten days le } \\
\text { cine manufac } \\
\text { A before } \\
\text { or } 1.888 \text { p } \\
\text { and the ATVA } \\
01526633 \text { or } \\
\text { e activity aft }\end{array}$ & \multicolumn{3}{|c|}{$\begin{array}{l}\text { before the vaccine manufacturing } \\
\text { announcement. The value of ATVA before and } \\
\text { after the vaccine manufacturing announcement } \\
\text { in the ten-day event window indicates that } \\
\text { market players (investors) have a negative } \\
\text { reaction to the vaccine manufacturing } \\
\text { announcement. } \\
\text { Figure } 7 \text { depicts the ATVA for each day } \\
\text { in the ten-day period preceding and following } \\
\text { the vaccine manufacturing announcement }\end{array}$} \\
\hline
\end{tabular}




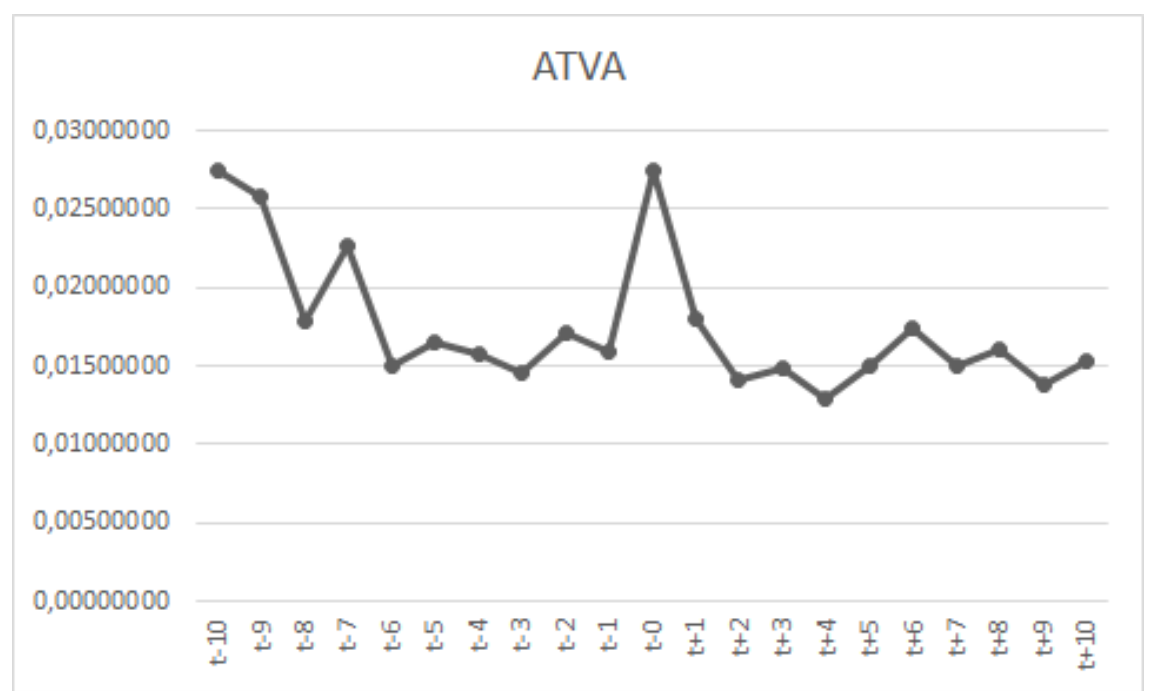

Figure 7: Average Trading Volume Activity for each day in ten days event window (Source: processed by author)

c. Five days event window

Table 6: Average Trading Volume Activity in five days event window (Source: SPSS 22.0, processed by author)

\begin{tabular}{lcccc}
\hline & Minimum & Mean & Maximum & Std. Deviation \\
\hline $\begin{array}{l}\text { Before } \\
\text { Announcement }\end{array}$ & 0.001559 & 0.01599814 & 0.07217 & 0.017663521 \\
\hline $\begin{array}{l}\text { During } \\
\text { Announcement }\end{array}$ & 0.001866 & 0.02753141 & 0.118161 & 0.030710571 \\
\hline $\begin{array}{l}\text { After } \\
\text { Announcement }\end{array}$ & 0.001508 & 0.01499528 & 0.060731 & 0.015260432 \\
\hline
\end{tabular}

Table 6 shows the descriptive statistics of trading volume activity in a five-day event window before and after the vaccine production announcement. The ATVA before vaccine manufacture is 0.01888454 or 1.888 percent for the whole companies, and the ATVA after vaccine manufacturing is 0.01599814 or 1.600 percent. The trading volume activity after the vaccine manufacturing announcement is, on average, lower than the trading volume activity before the vaccine manufacturing announcement. The value of ATVA before and after the vaccine manufacturing announcement in the five-day event window indicates that market players (investors) had a negative reaction to the vaccine manufacturing announcement.

Figure 8 depicts the ATVA for each day in the five-day period preceding and following the vaccine manufacturing announcement. 


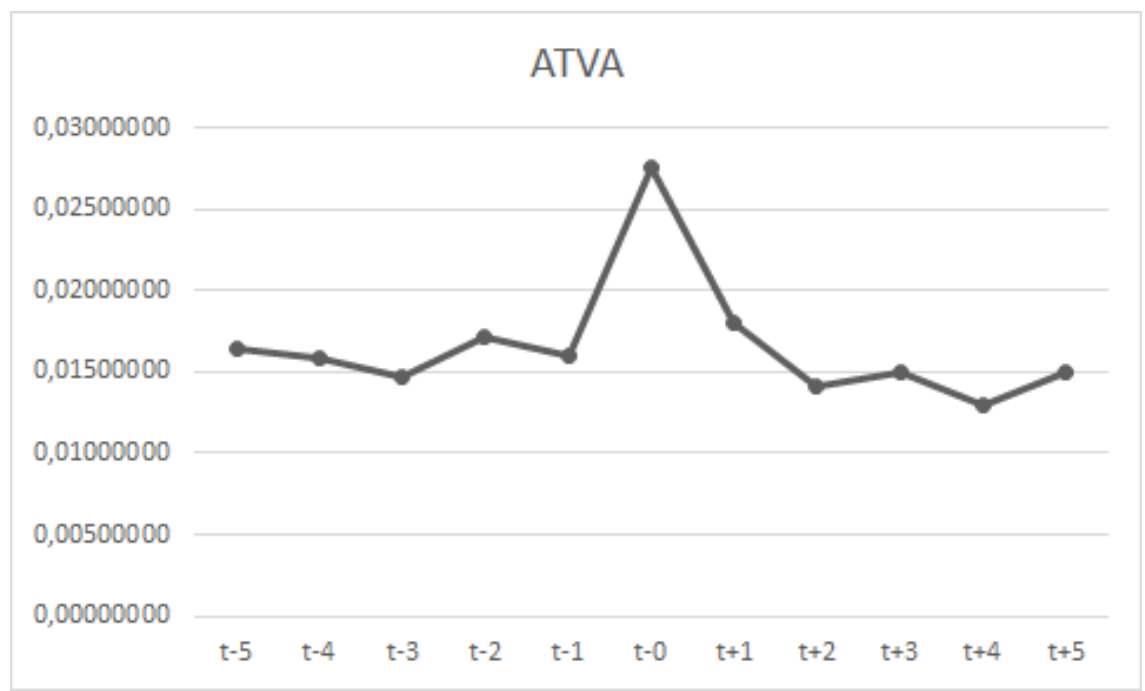

Figure 8: Average Trading Volume Activity for each day in five days event window (Source: processed by author)

Hypothesis Testing

a. One month event window

Table 7: Normality Test Result for Average Abnormal Return and Average Trading Volume Activity in one-month event window (Source: SPSS 22.0, processed by author)

\begin{tabular}{lcccc}
\hline \multicolumn{5}{c}{ Normality Test } \\
\hline P-value & AAR Before & AAR After & ATVA Before & ATVA After \\
\hline Normality & 0.001 & 0.011 & 0.000 & 0.001 \\
\hline $\begin{array}{l}\text { Statistical Hypothesis } \\
\text { Testing }\end{array}$ & No & No & No & No \\
\hline
\end{tabular}

Table 8: Statistical Hypothesis Test Result for Average Abnormal Return and Average Trading Volume Activity in one-month event window (Source: SPSS 22.0, processed by author)

\begin{tabular}{lccc}
\hline \multicolumn{1}{c}{ Variable } & Type of Testing & P-value & Conclusion \\
\hline $\begin{array}{l}\text { Average Abnormal } \\
\text { Return }\end{array}$ & $\begin{array}{c}\text { Paired Sample Wilcoxon } \\
\text { Signed Rank Test }\end{array}$ & 0.970 & No significant difference \\
\hline $\begin{array}{l}\text { Trading Volume } \\
\text { Activity }\end{array}$ & $\begin{array}{c}\text { Paired Sample Wilcoxon } \\
\text { Signed Rank Test }\end{array}$ & 0.093 & No significant difference \\
\hline
\end{tabular}

Table 7 shows that the AAR p-values in the one-month event window before and after the vaccine production announcement are 0.001 and 0.011 , respectively, which are less than the significance level (0.05), indicating that the data is not normally distributed. As a result, the Paired Sample Wilcoxon Signed Rank Test will be used to conduct the paired difference test.

The ATVA's p-values before and after the vaccine manufacturing announcement are 0.000 and 0.001 , respectively, which are less than the significance level $(=0.05)$, suggesting that the data is not normally distributed. As a result, the Paired Sample Wilcoxon Signed
Rank Test will be used to conduct the paired difference test.

The average abnormal return in the onemonth event window has a p-value of 0.970 , which is greater than the significance level $(0.05)$, indicating that $\mathrm{HO}$ is rejected and $\mathrm{H} 1$ is accepted, according to Table 8 . This suggests that the abnormal return one month before the vaccine manufacturing announcement and the abnormal return one month after the vaccine manufacturing announcement are not significantly different.

The average trade volume activity in the one-month event window has a $p$-value of 0.093, which is higher than the significance level (0.05), indicating that $\mathrm{HO}$ is rejected and 
$\mathrm{H} 2$ is accepted. This suggests that the trading volume activity one month before the vaccine manufacturing announcement and the trading volume activity one month after the vaccine manufacturing announcement are not significantly different.

a. Ten days event windoe

Table 9: Normality Test Result for Average Abnormal Return and Average Trading Volume Activity in ten days event windwow (Source: SPSS 22.0, processed by author)

\begin{tabular}{lcccc}
\hline \multicolumn{4}{c}{ Normality Test } \\
\hline & AAR Before & AAR After & ATVA Before & $\begin{array}{c}\text { ATVA } \\
\text { After }\end{array}$ \\
\hline P-value & 0.078 & 0.022 & 0.000 & 0.000 \\
\hline Normality & Yes & No & No & No \\
\hline $\begin{array}{l}\text { Statistical } \\
\text { Hypothesis }\end{array}$ & $\begin{array}{c}\text { Paired Sample } \\
\text { Testing }\end{array}$ & Wilcoxon Signed-Rank Test & Wilcoxon Signed-Rank Test \\
\hline
\end{tabular}

Table 10: Statistical Hypothesis Test Result for Average Abnormal Return and Average Trading Volume Activity in ten days event window (Source: SPSS 22.0, processed by author)

\begin{tabular}{lccc}
\hline & Type of Testing & P-value & Conclusion \\
\hline $\begin{array}{l}\text { Average Abnormal } \\
\text { Return }\end{array}$ & $\begin{array}{c}\text { Paired Sample Wilcoxon } \\
\text { Signed Rank Test }\end{array}$ & 0.550 & No significant difference \\
\hline $\begin{array}{l}\text { Trading Volume } \\
\text { Activity }\end{array}$ & $\begin{array}{c}\text { Paired Sample Wilcoxon } \\
\text { Signed Rank Test }\end{array}$ & 0.478 & No significant difference \\
\hline
\end{tabular}

The $p$-value of the AAR in the ten-day event window preceding the vaccine manufacturing announcement is 0.078 , which is greater than the significance level (0.05), indicating that the data is normally distributed, according to Table 9. Meanwhile, the AAR in the 10 days following the vaccine manufacturing announcement is 0.022 , which is less than the significance level (0.05), implying that the data is not normally distributed. The paired difference test will be performed using the Paired Sample Wilcoxon Signed Rank Test since one of the two linked variables is not normally distributed.

The ATVA's p-values before and after the vaccine production announcement are 0.000 and 0.000 , respectively, which are less than the significance level $(=0.05)$, suggesting that the data is not normally distributed. As a result, the Paired Sample Wilcoxon Signed Rank Test will be used to conduct the paired difference test.

Table 11: Normality Test Result for Average Abnormal Return and Average Trading Volume Activity in five days event window (Source: SPSS 22.0, processed by author)

\begin{tabular}{lcccc}
\hline \multicolumn{4}{c}{ Normality Test } \\
\hline & AAR Before & AAR After & ATVA Before & $\begin{array}{c}\text { ATVA } \\
\text { After }\end{array}$ \\
\hline P-value & 0.681 & 0.001 & 0.000 & 0.001 \\
\hline Normality & Yes & No & No & No \\
\hline $\begin{array}{l}\text { Statistical Hypothesis } \\
\text { Testing }\end{array}$ & Paired Sample & Paired Sample \\
\hline
\end{tabular}
abnormal return in the ten-day event window has a $p$-value of 0.550 , which is higher than the significance level (0.05), indicating that $\mathrm{HO}$ is rejected and $\mathrm{H} 1$ is accepted. This suggests that the abnormal return ten days before the vaccine manufacturing announcement and the abnormal return ten days after the vaccine manufacturing announcement are not significantly different.

The average trade volume activity in the ten-day event window has a p-value of 0.478 , which is higher than the significance level (0.05), indicating that $\mathrm{HO}$ is rejected and $\mathrm{H} 2$ is accepted. This means that the trading volume activity ten days before the vaccine manufacturing announcement and the trading volume activity ten days after the vaccine manufacturing announcement are not significantly different.

b. Five days event window ilcoxon Signed-Rank Test 
Table 12: Statistical Hypothesis Test Result for Average Abnormal Return and Average Trading Volume Activity in five days event window (Source: SPSS 22.0, processed by author)

\begin{tabular}{lccc}
\hline & Type of Testing & P-value & Conclusion \\
\hline $\begin{array}{l}\text { Average Abnormal } \\
\text { Return }\end{array}$ & $\begin{array}{c}\text { Paired Sample Wilcoxon } \\
\text { Signed Rank Test }\end{array}$ & 0.911 & No significant difference \\
\hline $\begin{array}{l}\text { Trading Volume } \\
\text { Activity }\end{array}$ & $\begin{array}{c}\text { Paired Sample Wilcoxon } \\
\text { Signed Rank Test }\end{array}$ & 0.502 & No significant difference \\
\hline
\end{tabular}

The $p$-value of the AAR in the five days event window preceding the vaccine production announcement is 0.681 , which is greater than the significance level $(a=0.05)$, indicating that the data is normally distributed, according to Table 11. In the meantime, the AAR in the fiveday event window following the vaccine production announcement is 0.001 , which is less than the significance level $(a=0.05)$, showing that the data is not normally distributed. The paired difference test will be performed using the Paired Sample Wilcoxon Signed Rank Test since one of the two linked variables is not normally distributed.

The ATVA's p-values before and after the vaccine manufacturing announcement are 0.000 and 0.001 , respectively, which are less than the significance level $(=0.05)$, suggesting that the data is not normally distributed. As a result, the Paired Sample Wilcoxon Signed Rank Test will be used to conduct the paired difference test.

The average abnormal return in the fiveday event window has a p-value of 0.911, which is greater than the significance level $(0.05)$, indicating that $\mathrm{HO}$ is rejected and $\mathrm{H} 1$ is accepted, according to Table 12 . This suggests that the abnormal return five days before the vaccine manufacturing announcement and the abnormal return five days after the vaccine manufacturing announcement are not significantly different.

The average trade volume activity in the five-day event window has a p-value of 0.502 , which is higher than the significance level (0.05), indicating that $\mathrm{HO}$ is rejected and $\mathrm{H} 2$ is accepted. This means that the trading volume activity five days before the vaccine manufacturing announcement and the trading volume activity five days after the vaccine manufacturing announcement are not significantly different.

For both the abnormal return and the trading volume activity for pharmaceutical businesses, all of the event windows (one month, ten days, and five days) reveal that there is no major market reaction to the announcement of vaccine manufacturing undertaken by the companies. This suggests that the vaccine manufacturing announcement had no impact on pharmaceutical businesses.

This finding does not necessarily imply that the vaccine manufacturing announcement had no effect. Both the average abnormal return and the average trading volume activity graphs demonstrate an uptick in market reaction on the day of the vaccine manufacturing announcement. Aside from that, the average value of the average abnormal return after the vaccine manufacturing announcement is higher than the average value of the average abnormal return before the vaccine manufacturing announcement, indicating that the vaccine manufacturing announcement resulted in a positive trend toward pharmaceutical companies from the day of the announcement until days later. The increase in the average abnormal return graphs, however, is not statistically significant.

Meanwhile, the average trading volume activity after the vaccine manufacturing announcement is lower than the average value of the trading volume activity before the vaccine manufacturing announcement, indicating that the vaccine manufacturing announcement gave a negative trend toward the pharmaceutical companies during the day of the vaccine manufacturing announcement until the days after the vaccine manufacturing announcement. This can be caused by other factors outside the vaccine manufacturing announcement since there are specific events for particular companies in the sample that affect their trading volume activity data. For example, the stock of Indofarma PT Tbk and Kimia Farma PT Tbk was suspended by the Indonesia Stock Exchange on August 7th, 2020 (day +12 after vaccine manufacturing announcement), resulting in their trading volume activity being zero on that day. Another example is the trading volume activity of Vaxart, Inc. that experienced a sudden increase on days -16 and -15 , then a sudden 
decrease on day -14 due to positive news followed by negative news.

The lack of a significant difference in abnormal return and trading volume activity suggests that the market was not overly receptive to the vaccine production news. In terms of the broader market reaction, this could be due to uncertainties about vaccine efficacy and side effects, especially since each company's vaccine manufacturing announcement date is different. The prior bad and good track record of a firm that disclosed vaccine manufacturing earlier may influence the purchasing decision of an investor in one's company. Negative news about the COVID-19 vaccine may cause investors to be pessimistic, especially if there is anticipation of a share price decrease, lowering investors' confidence in future profits, resulting in the investors' tendency to avoid risks.

\section{Conclusion}

The purpose of this study was to see if there is a substantial change in the capital market between before and after the announcement of vaccine manufacture for the period of December 1st, 2019 to July 1st, 2021, as evidenced by anomalous return and trading volume activity of the sample companies. The following are the results reached after extensive testing and discussion:

$\mathrm{H} 1$ is the first hypothesis that has been accepted. The anomalous return of the three event windows does not differ significantly. However, the average value of the abnormal return after the vaccine manufacturing announcement is higher than the value of the abnormal return before the vaccine manufacturing announcement. This suggests that the vaccine production announcement has an impact on pharmaceutical businesses' anomalous returns, as evidenced by a favorable tendency over both long and short time periods. The influence, however, is not statistically significant.

$\mathrm{H} 2$ is the second hypothesis that has been accepted. The trade volume activity of the three event windows does not differ significantly. However, the average value of trading volume activity after the vaccine production announcement is lower than the value of trading volume activity prior to the vaccine manufacturing announcement. This suggests that the vaccine manufacturing announcement has a negative impact on pharmaceutical businesses' trading volume activity, as evidenced by a downward trend in both long- and short-term timeframes. The influence, however, is not statistically significant.

Because the capital markets are not particularly stable, the ultimate conclusion of a not significant difference in abnormal return and trading volume activity before and after pharmaceutical companies announce vaccine manufacturing could be influenced by investors' desire to avoid risks. During the epidemic, it's possible that investors elected to take a waitand-see approach to investing.

After looking at the data, it's possible to conclude that the market isn't highly responsive to the specific event, which is the vaccine manufacturing announcement. However, the author understands that, based on the research findings and literature review, the capital market of pharmaceutical companies is categorized in the semi-strong form of market efficiency, because news of vaccine manufacturing is reflected in the share price of the companies as soon as the vaccine manufacturing is announced to the public, despite the fact that the difference shown by the variables (abnormal return and trading volume activity) was not significant. This is based on the theory of (Tandelilin, 2010), which states that all released information reflects the security prices of the semi-strong type of market efficiency. The publicized information can be in the form of information, such as the vaccine manufacturing announcement in this example.

\section{References}

Baker, Scott R., Bloom, Nicholas, Davis, Steven J., \& Terry, Stephen J. (2020). Covidinduced economic uncertainty. National Bureau of Economic Research. Google Scholar

Baldwin, Richard, \& Di Mauro, B. Weder. (2020). Economics in the time of COVID19: A new eBook. VOX CEPR Policy Portal, 2-3. Google Scholar

Bash, A. (2020). International Evidence of COVID-19 and Stock Market Returns: An Event Study Analysis. International Journal of Economics and Financial Issues, 34-38. Google Scholar 
Gupta, M. (2014). Stock Market Reaction to Shares Buyback in India: An Event Study Methodology. International Journal of Trend in Research and Development.

Hartono. (2014). Teori Portofolio dan Analisis Investasi Edisi 8. Yogyakarta.

rHartono, J. (2017). Teori Portofolio dan Analisis Investasi. Yogyakarta: BPFE.

Khoiriah, M., Amin, M., \& Kartikasari, A. F. (2020). PENGARUH SEBELUM DAN SAAT ADANYA PANDEMI COVID-19 TERHADAP SAHAM LQ-45 DI BURSA EFEK INDONESIA TAHUN 2020. Malang: Jurnal Ilmiah Riset Akuntansi. Google Scholar

Mujib, B., \& I. R. (2021). Capital Market Reaction to Covid-19 Pandemic on LQ45 Shares at Indonesia Stock Exchange (IDX). American Journal of Humanities and Social Sciences Research, 74-80. Google Scholar

Pitaloka, Herninda, Al Umar, Ahmad Ulil Albab, Hartati, Eka Resmi, \& Fitria, Dessy. (2020). The economic impact of the COVID-19 outbreak: Evidence from Indonesia. Jurnal Inovasi Ekonomi, 5(02). Google Scholar

Pratama, I. Gede Bhakti, Sinarwati, Ni Kadek, Darmawan, Nyoman Ari Surya, \& SE, Ak. (2015). Reaksi pasar modal indonesia terhadap peristiwa politik (Event study pada peristiwa pelantikan Joko Widodo sebagai presiden Republik Indonesia ke7). JIMAT (Jurnal IImiah Mahasiswa Akuntansi) Undiksha, 3(1). Google Scholar

Priyatno, Duwi. (2012). Cara kilat belajar analisis data dengan SPSS 20. Yogyakarta: Andi Offset. Google Scholar

Razali, Nornadiah Mohd, \& Wah, Yap Bee. (2011). Power comparisons of shapirowilk, kolmogorov-smirnov, lilliefors and anderson-darling tests. Journal of Statistical Modeling and Analytics, 2(1), 21-33. Google Scholar

Rofiki, David, Topowijono, Topowijono, \& Nurlaily, Ferina. (2018). Reaksi Pasar Modal Indonesia Akibat Peristiwa Pemilihan Gubernur Dki Jakarta Putaran Ii 2017 (Event Study Pada Saham Perusahaan Yang Terdaftar Di Indeks Lq45 Periode Februari-Juli 2017). Jurnal Administrasi Bisnis, 62(2), 185-193. Google Scholar

Tandelilin, Eduardus. (2010). Teori dan Aplikasi Portofolio dan Investasi. Yogyakarta: Kanisius. Google Scholar

Woolson, R. F. (2007). Wilcoxon signed-rank test. Wiley Encyclopedia of Clinical Trials, 1-3. Google Scholar

\section{Copyright holder : \\ Cellina Trishana (2022)}

First publication right :

Journal of Social Science

This article is licensed under:

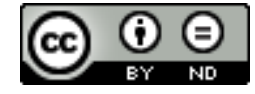

